\section{Quality Evaluation of Sorghum bicolor Stem Sheath Enriched with Spondias mombin Extract}

\author{
Adedeji TO* \\ Department of Food Science and Technology, Osun State Polytechnic, Iree, Nigeria
}

\section{Abstract}

The nutritional compositions of sorghum stem sheath-Spondias mombin extract were evaluated. The enriched stem sheath extract were obtained by mixing sorghum stem sheath and Spondias mombin (iyeye) extract in varied proportions at 100:0; 0:100; 95:5; 90:10 and 85:15. The five samples were subjected to analysis: proximate, mineral, vitamin C, antinutrient composition. Data obtained were analysed using descriptive and inferential statistics. The result showed that observable increases were noticed in proximate, vitamin $\mathrm{C}$ and mineral composition from $5 \%$ inclusion of Spondias mombin extract in sorghum stem sheath drinks. The anti-nutrient compositions: tannin, oxalate and saponin, ranged from $(0.144$ to $0.442,0.303$ to $0.385,0.070$ to 0.198$) \mathrm{mg} / 100 \mathrm{ml}$, respectively for sorghum stem sheath- Spondias mombin extract which were within consumable safe limits. The study concluded that nutritious enriched drinks could be produced from sorghum stem sheath and Spondias mombin extract at ambient temperature.

\section{More Information}

*Address for Correspondence: Adedeji TO, Department of Food Science and Technology, Osun State Polytechnic, Iree, Nigeria, Tel: 08066514332;

Email temileyeadedeji2@gmail.com

Submitted: 17 April 2020

Approved: 01 June 2020

Published: 03 June 2020

How to cite this article: Adedeji TO. Quality Evaluation of Sorghum bicolor Stem Sheath Enriched with Spondias mombin Extract. Arch Food Nutr Sci. 2020; 4: 012-019.

DOI: 10.29328/journal.afns.1001022

Copyright: @ 2020 Adedeji TO. This is an open access article distributed under the Creative Commons Attribution License, which permits unrestricted use, distribution, and reproduction in any medium, provided the original work is properly cited.

Keywords: Proximate; Extract; Spondias mombin; Sorghum stem sheath

Check for updates

OPEN ACCESS

\section{Introduction}

Sorghum is originally a wild plant in Africa, Sudan and central Asia which belongs to the family of Poaceae. The common names include millet, guinea corn, broom corn, sweet sorghum etc. In Nigeria languages, it is called Okababa (Yoruba), dawa/jero (Hausa) and soro (Igbo). The parts that are commonly used for herbal drugs include leaves, stem or grains. Different types of Sorghum bicolor are recognized including grain sorghums, sweet sorghums, and grass sorghums. It is known by a variety of names, including milo or milo-maize in the United State, dura in Sudan, great millet and guinea corn in West Africa, kafir corn in South Africa, mtama in eastern Africa and jowar in India [1]. Sorghum (Sorghum bicolor (L) Moench) is valued for its grain, stalks and leaves. It is one of the World's major cereal crops. Worldwide, there are a small number of grains that supply approximately $85 \%$ of the world's food energy and only four other foods (rice, wheat, maize, and potatoes) are consumed more than sorghum. For 500 million people in over 30 countries of the semi-arid tropics, sorghum is a dietary staple. Sorghum stem sheath is popularly called 'Karandasi' or 'poroporo baba' within many localities in Nigeria and being claimed by a reasonable number of herb sellers to cure anaemia. The blood "tonic" is usually prepared by boiling the karandasi in water for 20-30 min and taken between 5 and 7 days. The method of production is as described by Adetuyi, et al. [2]. Sorghum stem sheath is soaked for 10 mins at ambient temperature before boiling for 30 mins. The extract is then filtered with cleaned muslin cloth to obtain clear solution. The liquid extracts were filtered through a 0.22 micron cellulose acetate filter to produce a sterile stock solution. The filtrate can be sweetened using food grade sucrose/honey according to individual's preference.

Spondias mombin tree is native and common in most lowland forests, and indigenous to tropical Africa [3]. The true yellow mombin, S. mombin L. (Syn. S. lutea L.) is most often called hog plum in the Carribean Islands [4,5]. In Jamaica, it is also known as Spanish plum, or gully plum. The yellow mombin is appreciated mostly by children and passers-by as means of alleviating thirst [6]. It is effective against anaemia, angina, anxiety, abortifacient, analgesic, anthelmintic but mostly effective against ascaris (worms). It contains carbobydrate, flavonoids, tannins, protein and sterols, it tastes sweet and sour [7]. The purple mombin (Spondias purpurea L.) is stewed whole, with sugar, and consumed as dessert [8], and can be preserved for future use merely by boiling and drying, which keeps the fruit in good condition for several months [8]. In Florida, yellow mombin is sold in local markets and consumed fresh; and it makes a significant contribution to the diet of people in local areas of the tropics when in season [7]. Data from various sources have identified increased consumption of the fruit of Spondias mombin as food in raw and processed form as a result of great taste (which ranges from sour to sour 
sweet), good levels of minerals, vitamins, low levels of lipids and reducing sugars [8-12]. Recent studies also suggest that the fruit of Spondias mombin is a rich source of antioxidants and phenols, minerals, phytonutrients, organic acids, phytosterols, terpenoids, and carotenoids [13-15]. Findings have established it as a potential source of highly nutritious feed stuff, folk medicine and phytomedicine as a result of its aromatic, astringent and refrigerant nature [8,13,16-18]. The tree exudes gum used as glue; root and bark decoctions are used as purgatives and remedies for diarrhea, dysentery and haemorrhoids [8], while leaves extract have been reported to have anxiolytic [19], anathematic, sedative, antiepileptic and antipsychotic [16], hypoglycaemic [20], in vitro antioxidant [21], and antimicrobial effects [22].

Research efforts are being directed towards utilizing locally available raw materials in food and beverage formulation. Indigenous beverages have been developed with great success and these include zobo and kunnu zaki $[23,24]$. With increased awareness of the consumers of diet related health problems, the emphasis has been to reduce chemical addition in food formulation including beverage. In the last few decades, interest in scientific research has shifted to plant materials having nutraceutical properties [25]. Recently, emphasis has been placed on foods that are useful in the prevention and treatment of diseases. The native plants like sorghum stem sheath and Spondias mombin fruits are usually under-explored in spite of their enormous nutritional and medicinal benefits in many countries. Adetuyi, et al. [2] reported that sorghum stem sheath lacks vitamin C which is abundant in Spondias mombin fruits. So, it is essential to explore the potential of indigenous plants through the development of innovative functional drinks. The established data on the nutritional composition of Spondias mombin fruits is an indication that they have potential to be used as a food additive with multiple purposes [5]. Spondias mombin can also serve as a protein, antioxidants, and fatty acid, mineral and vitamin sources for drink formulation. Although considerable amount of literature exists on the nutrient composition of sorghum stem sheath, however, there is a dart of information about its enrichment with Spondias mombin extract. This study therefore seeks to investigate its possible proximate and nutrient compositions so as to unravel new information to improve health and nutrition (Plates 1,2).

\section{Materials and methods}

\section{Materials}

Sorghum stem sheath was purchased from Oja-oba market in Akure, Ondo State, Nigeria while Spondias mombin (iyeye) fruits were collected from a local farm in Akure, Ondo State. All chemicals used for analyses were of analytical grade. These chemicals were procured from Fisher Scientific (Oakville, ON, Canada) and Sigma Chemicals (St. Louis, MO).

\section{Methods}

Production of Spondias mombin extract: The method

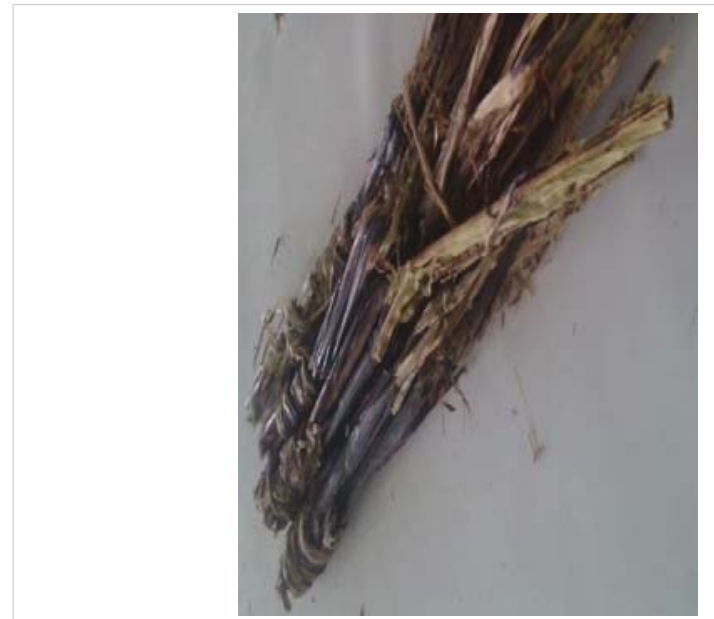

Plate 1: Sorghum stem sheath.

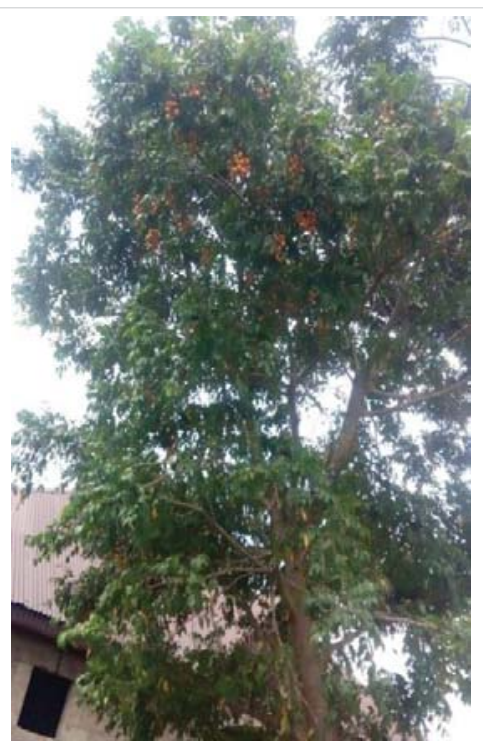

Plate 2: Spondias mombin tree with fruits.

described by Tiburski, et al. [14], was adapted with some modifications. About $200 \mathrm{~g}$ of Spondias mombin fruits were sorted and washed to remove extraneous materials. The pulps were extracted with $3000 \mathrm{ml}$ of water manually by hand and sieved with a clean muslin cloth. The liquid extract was decanted into sterilized bottles and kept in a refrigerator for further use.

Production of sorghum stem-sheath-Spondias mombin extract: The method described by Adetuyi, et al. [2] was adapted with some modifications. Dried sorghum stem sheath was freed from extraneous materials by manual sorting and winnowing. About $400 \mathrm{~g}$ of the stem sheath was weighed and washed slightly with water. The washed stem sheath was boiled thoroughly in $6000 \mathrm{ml}$ of water for 30 mins to aid the extraction as well as destruction of heat sensitive micro-organisms present. It was then filtered into previously sterilized bowl using a clean muslin cloth to obtain sorghum stem drink. Spondias mombin extract was added at different concentrations [0, 5, 10 and $15 \%(\mathrm{v} / \mathrm{v})]$ for enrichment. Each sample was stirred and boiled for 5 mins to prevent 
post production contamination. The samples were bottled immediately, pasteurized at $70{ }^{\circ} \mathrm{C}$ for 15 mins, cooled slowly under running water and stored at ambient temperature $(27$ $\pm 2{ }^{\circ} \mathrm{C}$ ). Sorghum stem sheath - Spondias mombin extract and sample designation is shown in table 1.

\section{Proximate analysis of sorghum stem sheath- Spondias mombin extract}

The samples were analyzed for moisture content, crude fat, crude protein, ash content, crude fibre based on the method of analysis of the association of official analytical chemists [26]. Carbohydrate content was calculated by difference.

\section{Mineral element and vitamin C analysis of sorghum stem sheath- Spondias mombin extract}

The analysis for essential mineral elements was carried out by atomic absorption spectrophotometric using the method of Fashakin, et al. [27]. Ascorbic acid concentration in the enriched drink was determined using the method of Hassan and Hassan [28].

\section{Determination of anti-nutritional constituents of sorghum stem sheath- Spondias mombin extract}

Oxalate content was determined using the method of Edet, et al. [29]. Tannin was determined according to the modified vanillin - hydrochloric acid ( $\mathrm{MV}-\mathrm{HCl}$ ) method of Price, et al. [30]. Saponin was determined according to the spectrophotometric method of Brunner [31].

\section{Statistical analysis}

All data were subjected to one-way Analysis of Variance and means were separated using Duncan's multiple range tests using SPSS for Windows version 16. The flow chart for the production of sorghum stem sheath-Spondias mombin drink is shown in figure 1.

\section{Results and discussion}

\section{Proximate compositions (\%) of sorghum stem sheath- Spondias mombin extract}

The proximate composition of the sorghum stem sheath -Spondias mombin extracts are presented in table 2. This showed increases in crude fat, ash, protein and moisture content with decrease in carbohydrate content of the enriched extract. The moisture content of the enriched sorghum stem sheath increased insignificantly $(p>0.05)$ from $(87.71 \%$

Table 1: Sorghum stem sheath - Spondias mombin Extract and Sample Designation.

\begin{tabular}{|c|c|}
\hline Sample Code & Sample Designation \\
\hline SS100SM0 & Sorghum stem sheath Extract- Control \\
\hline SM100SS0 & Spondias mombin Extract-Control \\
SS95SM5 & $95 \%$ Sorghum stem sheath \\
& $+5 \%$ Spondias mombin Extract \\
\hline SS90SM10 & $90 \%$ Sorghum stem sheath \\
& $+10 \%$ Spondias mombin Extract \\
\hline SS85SM15 & $85 \%$ Sorghum stem sheath \\
& $+15 \%$ Spondias mombin Extract \\
\hline
\end{tabular}

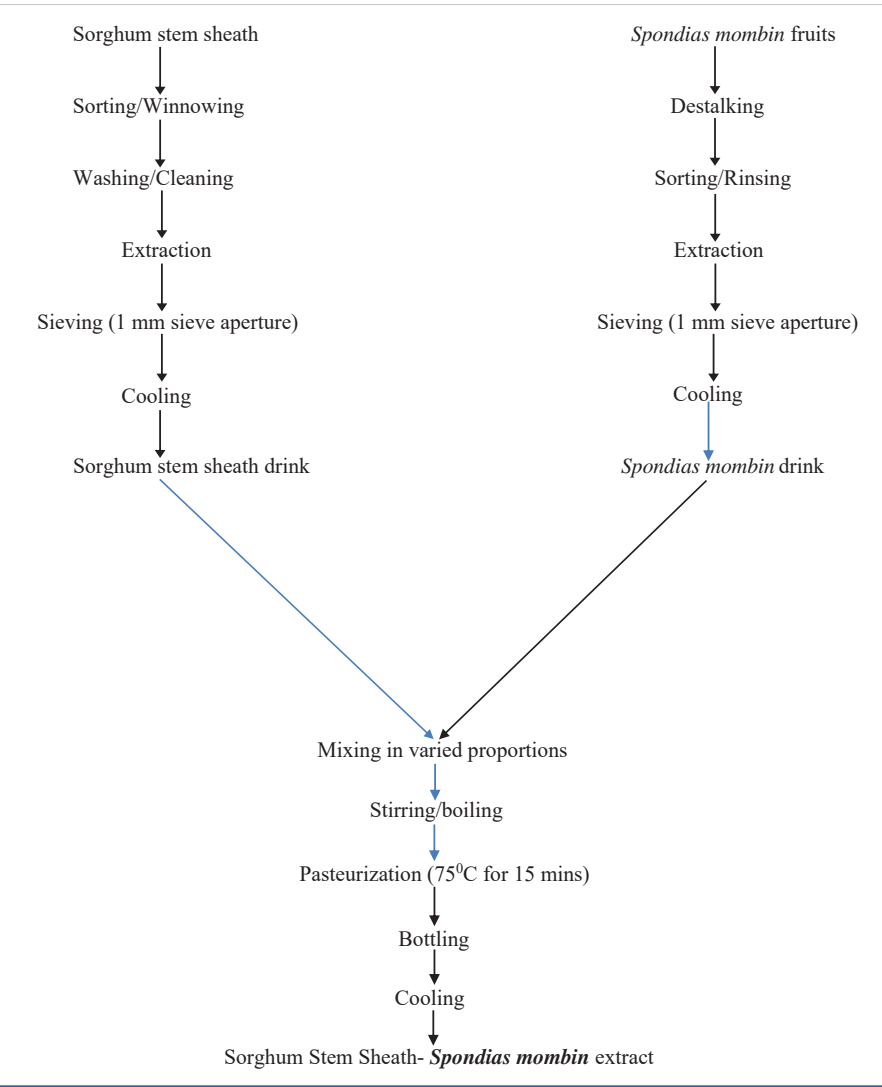

Figure 1: Flow chart for the production of Sorghum stem sheath-Spondias mombin Extract.

Source: Tiburski, et al. (2011); Adetuyi, et al. (2007) modified.

to $87.01 \%$ ) with increased inclusion of Spondias mombin extract. The moisture content of the stem sheath $(88.00 \%)$ was relatively lower than other recorded values like Moringa oleifera extract $(90.00 \%)$ [32]. The high moisture content of enriched samples may be due to high amount of water used for the extraction which underpins its role as thirst quenching characteristics $[33,34]$.

The ash content increased insignificantly $(p>0.05)$ from $(0.34 \%$ to $0.42 \%)$ with increased inclusion of Spondias mombin extract. The ash content of the stem sheath $(0.30 \%)$ was relatively higher than Moringa oleifera extract $(0.20 \%)$ [35]. The ash in food determines largely the extent of mineral matters likely to be found in the food substance which nutritionally aids the metabolism of other organic compounds, such as protein and fat [36]. Plant materials are known to be rich sources of mineral elements. Ashing is usually carried out in order to evaluate the mineral matter of food [37].

The fat content increased insignificantly $(p>0.05)$ from $(0.109 \%$ to $0.340 \%)$ with increased inclusion of Spondias mombin extract. The fat content of the stem sheath $(0.009 \%)$ was relatively lower than other recorded values like Piliostigma thonningii extract (1.42\%) [38]. However, the lower amount of fat $(0.109 \%$ to $0.340 \%)$ in the samples can be used as diet drink and preventive measures for other chronic diseases [39]. The koronye and Ngoddy [40] reported that fat should be less than $5 \%$ in juices and drinks since this could 
Table 2: Proximate Composition (\%) of Sorghum Stem Sheath- Spondias mombin Extracts.

\begin{tabular}{|c|c|c|c|c|c|}
\hline Sample & Moisture & Fat & Protein & Ash & $\mathrm{CHO}$ \\
\hline SS100SM0 & $88.00 \pm 0.01^{a}$ & $0.009 \pm 0.004^{d}$ & $0.050 \pm 0.005^{d}$ & $0.30 \pm 0.05^{d}$ & $11.64 \pm 0.01^{a}$ \\
\hline SM100SS0 & $82.28 \pm 0.05^{d}$ & $2.00 \pm 0.03^{a}$ & $2.60 \pm 0.02^{\mathrm{a}}$ & $1.00 \pm 0.01^{a}$ & $8.00 \pm 0.05^{d}$ \\
\hline SS95SM5 & $87.71 \pm 0.03^{c}$ & $0.109 \pm 0.003^{c}$ & $0.178 \pm 0.004^{c}$ & $0.34 \pm 0.04^{c}$ & $11.46 \pm 0.02^{b}$ \\
\hline SS90SM10 & $87.43 \pm 0.02^{c}$ & $0.208 \pm 0.002^{c}$ & $0.305 \pm 0.002^{c}$ & $0.37 \pm 0.03^{c}$ & $11.27 \pm 0.03^{b}$ \\
\hline SS85SM15 & $87.01 \pm 0.04^{b}$ & $0.340 \pm 0.001^{b}$ & $0.495 \pm 0.003^{b}$ & $0.42 \pm 0.02^{b}$ & $10.99 \pm 0.04^{c}$ \\
\hline
\end{tabular}

Note: SS100SM0 = sorghum stem sheath extract, SM100SS0 = Spondias mombin extract, SS95SM5 = 95\% sorghum stem sheath $+5 \%$ Spondias mombin extract, SS90SM 10 $=90 \%$ sorghum stem sheath $+10 \%$ Spondias mombin extract, SS85SM $15=85 \%$ sorghum stem sheath $+15 \%$ Spondias mombin extract, Values are means \pm standard deviation of triplicate determinations. The mean values along the same column with different superscripts are significantly different $(p<0.05)$.

result to rancidity leading to the development of unpleasant and odorous compounds.

The protein content increased insignificantly $(p>0.05)$ from $(0.178 \%$ to $0.495 \%)$ with increased inclusion of Spondias mombin extract. Although the crude protein of sorghum stem sheath (0.050) \% was lower compared to the Abelmoschus esculentus extract (41.1\%) [41] and Adasonia digitata extract (21.8\%) [42] and Bombax glabra extract (34.1\%) [14], it is also lower than the results of other tropical plant seeds extract like the Sesemum indicum (11.6\%) [43] and Annona muricata (2.4\%) [44]. Protein is an essential building material in food necessary for the maintenance of all body parts, such as blood, hair, bones, brain, nails, skin muscles and body fluid (Ayo, et al. 2007).

Carbohydrate content of the enriched samples was obtained by difference which decreased insignificantly ( $p<$ 0.05 ) from $(11.46 \%$ to $10.99 \%$ ) with increased inclusion of Spondias mombin extract. The total carbohydrate of the stem extract $(11.64 \%)$ content is lower than Cola millenii extract (37.8\%) [14], Annona muricata extract (47.1\%) [44] and Adasonia digitata extract (52.5\%) [42]. The stem samples submits as potential source of carbohydrates that could be used as a good supplement to the scarce cereal grains in Nigeria as sources of energy in diet.

Mineral compositions ( $\mathrm{mg} / 100 \mathrm{ml}$ ) of sorghum stem sheath- Spondias mombin extracts

The mineral compositions of sorghum stem sheathSpondias mombin extract are shown in table 3. The calcium contents of the enriched samples decreased insignificantly ( $p$ $<0.05$ ) from (601.99 to 526.97) $\mathrm{mg} / 100 \mathrm{ml}$ with increased inclusion of Spondias mombin extract. The calcium content of the stem sheath (632.00) mg/100 ml was significantly higher when compared with Moringa oleifera leaf extract (84.73) mg/100 ml [32], Piliostigma thonningii extract (43.11 $\mathrm{mg} / 10 \mathrm{ml}$ ) [38], Lophira lanceolata extract (30 mg/100 ml) [45]. Sesemum indicum extract (281 mg/100ml) [43] and Cola millenii extract (168.35 mg/100 ml) [46]. The increased Ca content suggests that the enriched extract may be useful for the transport of oxygen and cellular activity. The Recommended Daily Allowance (RDA) ranged between 400 and $1200 \mathrm{mg}$ per day for infants, children and young adults [47]. Consumption of the enriched samples will definitely contribute to the RDA of calcium in infants and adults and enhance the health status of the consumers. Functions of calcium include bone mineralization, muscle contraction, cell signaling and regulation of cell metabolism. It can also mediate the death of a cell or a group of cells [47].

The sodium contents of sorghum stem sheath- Spondias mombin extract decreased insignificantly $(p<0.05)$ from (761.01 to 713.50$) \mathrm{mg} / 100 \mathrm{ml}$ with increased inclusion of Spondias mombin extract. The sodium content of the stem sheath (780.00) $\mathrm{mg} / 100 \mathrm{ml}$ was relatively higher than Moringa Oleifera extract (40.10 mg/100 ml) [35]. Sodium intake in the enriched drink may activate, the $\mathrm{Na}^{+} / \mathrm{K}^{+}$pump. This may cause influx of $\mathrm{K}^{+}$into the intracellular fluids and efflux of $\mathrm{Na}^{+}$, accompanied with $\mathrm{Cl}^{-}$and water, thereby resulting in possible reduction in blood pressure. This could account for the acclaimed diuretic effect and consequently the antihypertensive effects of sorghum stem sheath extract as claimed by Adedayo, et al. and Awika, et al. [48,49].

The iron content of sorghum stem sheath-moringa instant extract decreased insignificantly $(p<0.05)$ from $(108.46$ to 94.61$) \mathrm{mg} / 100 \mathrm{ml}$ with increased inclusion of Spondias mombin extract. The iron of the stem sheath extract (114.00) $\mathrm{mg} / 100 \mathrm{ml}$ was higher compared to Lophira lanceolata extract (40 mg/100 ml) [45], Cola millenii extract (48 mg/100 $\mathrm{ml})$ [46], Sesemum indicum extract $(38.3 \mathrm{mg} / 100 \mathrm{ml})$ [43] and Piliostigma thonningii extract (78.70 mg/100 $\mathrm{ml}$ ) [38]. The results showed that the enriched samples serve as good

Table 3: Minerals and Vitamin C Composition (mg/100ml) of Sorghum Stem Sheath- Spondias mombin Extracts.

\begin{tabular}{|c|c|c|c|c|c|}
\hline Sample & $\mathrm{Na}$ & $\mathrm{Ca}$ & $\mathbf{K}$ & $\mathrm{Fe}$ & Vit C \\
\hline SS100SM0 & $780.00 \pm 0.01^{a}$ & $632.00 \pm 0.02^{\mathrm{a}}$ & $123.04 \pm 0.06^{d}$ & $114.00 \pm 0.03^{a}$ & $0.00 \pm 0.00$ \\
\hline SM100SS0 & $400.10 \pm 0.05^{d}$ & $31.80 \pm 0.05^{d}$ & $270.02 \pm 0.01^{a}$ & $3.18 \pm 0.09^{d}$ & $34.01 \pm 0.01^{\mathrm{a}}$ \\
\hline SS95SM5 & $761.01 \pm 0.03^{b}$ & $601.99 \pm 0.01^{b}$ & $130.39 \pm 0.02^{c}$ & $108.46 \pm 0.05^{b}$ & $1.70 \pm 0.04^{c}$ \\
\hline SS90SM10 & $742.01 \pm 0.04^{b}$ & $571.96 \pm 0.03^{b}$ & $137.74 \pm 0.03^{c}$ & $102.92 \pm 0.06^{b}$ & $3.40 \pm 0.03^{c}$ \\
\hline SS85SM15 & $713.50 \pm 0.02^{c}$ & $526.97 \pm 0.04^{c}$ & $148.77 \pm 0.04^{b}$ & $94.61 \pm 0.07^{c}$ & $5.19 \pm 0.02^{b}$ \\
\hline
\end{tabular}

Note: SS100SM0 = sorghum stem sheath extract, SM100SS0 = Spondias mombin extract, SS95SM5 = 95\% sorghum stem sheath + 5\% Spondias mombin extract, SS90SM10

$=90 \%$ sorghum stem sheath $+10 \%$ Spondias mombin extract, SS 85 SM $15=85 \%$ sorghum stem sheath $+15 \%$ Spondias mombin extract, Values are means \pm standard deviation of triplicate determinations. The mean values along the same column with different superscripts are significantly different $(p<0.05)$. 
sources of iron. This confirms its traditional use of sorghum stem sheath in the prevention of anemia [50]. The values are in accordance to RDA of iron-10 mg/100 g to $13 \mathrm{mg} / 100 \mathrm{~g}$ for children; $7 \mathrm{mg} / 100 \mathrm{~g}$ for men; and $12 \mathrm{mg} / 100 \mathrm{~g}$ to 16 $\mathrm{mg} / 100 \mathrm{~g}$ for women and feeding mothers [51]. It is also important for cytochrome activity, urea cycle, lipogenesis and cholesterogenesis [52].

The potassium contents of sorghum stem sheath-Spondias mombin extractranged from 130.39 to $148.77 \mathrm{mg} / 100 \mathrm{ml}$ wich increased insignificantly $(p>0.05)$ with increased inclusion of Spondias mombin extract to sorghum stem sheath extract. The potassium content of the stem sheath (123.04) mg/100 $\mathrm{ml}$ was relatively higher than Moringa Oleifera extract (178.24 $\mathrm{mg} / 100 \mathrm{ml}$ ) [35]. Therefore, Spondias mombin extract is a potassium rich product. The increasing trend observed in this study also suggests that both Spondias mombin and sorghum stem sheath are good sources of mineral elements. Potassium is the principal intracellular cation of most body tissues [36]. Potassium rich diet is used therapeutically in patients with uncomplicated essential hypertension. Natural potassium sources such as food and drinks are used for treatment or supplement [54]. The results suggest that Spondias mombin could be a good source of calcium, magnesium, iron, where intakes of 150 - $1000 \mathrm{~g}, 160-850 \mathrm{~g}, 8-32 \mathrm{~g}$ would meet the Adequate Intake (AI) and Recommended Dietary Allowance for these minerals respectively [55].

The vitamin $C$ contents of the enriched samples are shown in table 3 which increased insignificantly $(p>0.05)$ from $(0.00$ to $5.19 \%)$ with increased inclusion of Spondias mombin extract. The vitamin $C$ content of the stem sheath $(0.00)$ $\mathrm{mg} / 100 \mathrm{ml}$ was relatively lower than Moringa Oleifera extract (4.43 mg/100 ml) [35]. Lack of vitamin C in the stem sheath is in agreement with the report of USDA Nutrient data base [56] that sorghum stem sheath does not contain vitamin C. Gbadegesin, et al. [57] reported that the vitamin C status of beverages (such as zobo) can be improved by blending with plant materials and fruits. Adetuyi, et al. [2] obtained a similar result for vitamin $\mathrm{C}$ content of sorghum stem sheath extract $(0.00 \%)$ when fortified with 50\%, 60\%, 70\%, 80\% and $90 \%$ orange and pineapple juices and reported proportionate values of $0.7,1.3,2.1,2.8$ and $3.5 \mathrm{mg} / 100 \mathrm{ml}$ and $(0.5,0.9$, 1.2, 1.7 and 2.1$) \mathrm{mg} / 100 \mathrm{ml}$ in the vitamin $\mathrm{C}$ content of the blends, respectively. Vitamin C is a powerful water-soluble antioxidant that boosts the immune system and helps prevent cancer and heart disease [58]. Vitamin C requirements may be higher in stressed or traumatized persons or in persons with diabetes mellitus [52]. The RDA ranged between 30 to $60 \mathrm{mg}$ per day for infants, children and adults. Consumption of the enriched drink will help provide some of the needed nutrients to meet the Recommended Daily Intake (RDI).

\section{Anti- nutrient composition $(\mathrm{mg} / 100 \mathrm{ml})$ of sorghum stem sheath-Spondias mombin extract}

The result for the anti- nutrients composition of sorghum stem sheath-Spondias mombin samples is represented in table 4. Moderate levels of tannin were also found to be present in the enriched samples $(0.025) \mathrm{mg} / 100 \mathrm{ml}$ which is within the safe level (5.6 mg/day) [59]. A tannin content up to $5.6 \mathrm{mg}$ is allowed in foods, and the intake of tannins present in the sorghum stem sheath extract $(0.025) \mathrm{mg} / 100 \mathrm{ml}$ was found to be much lower than that of zobo drink $0.035 \mathrm{mg} / 100 \mathrm{ml}$ [60] and Moringa Oleifera extract (0.3410 mg/100 ml) [32]. The tannin content of the enriched extracts ranged between $(0.144$ and 0.442$) \mathrm{mg} / 100 \mathrm{ml}$ which increased insignificantly $(p>0.05)$ with increased inclusion of Spondias mombin extract. The levels of this tested anti-nutrient in the enriched samples were very low and within the tolerable (safe) levels for man (5.60 mg/day) [61].

The oxalate content of the enriched stem samples $(0.303$ and 0.385$) \mathrm{mg} / 100 \mathrm{ml}$ which increased insignificantly $(p>$ 0.05 ) with increased inclusion of Spondias mombin extract was within the safe level of consumption in humans since the lowest lethal dose reported is $5 \mathrm{~g}$ (about $70 \mathrm{mg} / \mathrm{kg}$ ) [62] and so therefore $40-50 \mathrm{mg} /$ day is recommended [63]. The oxalate content of the stem sheath $(0.220) \mathrm{mg} / 100 \mathrm{ml}$ was relatively lower than Moringa Oleifera extract (3.3 10mg/100 ml) [32]. Mubarak, and Fasoyiro [64,65] reported that processing techniques could inactivate some food enzymes and degrade the anti-nutrients by leaching the toxic component into hot water. Albihn and Salvage [66] reported that boiling may cause considerable skin (epidermal) rupture and facilitate the leakage of soluble oxalate into boiling water. The levels of this tested anti-nutrient in the enriched samples were low and within the tolerable (safe) levels for man (10 mg/day) [59].

Table 4: Anti nutrient Composition $(\mathrm{mg} / 100 \mathrm{ml})$ of Sorghum Stem Sheath- Spondias mombin Extract.

\begin{tabular}{|c|c|c|c|}
\hline Sample & Tannin & Oxalate & Saponin \\
\hline SS100SM0 & $0.025 \pm 0.005^{d}$ & $0.220 \pm 0.004^{d}$ & $0.018 \pm 0.002^{d}$ \\
\hline SM100SS0 & $2.40 \pm 0.02^{\mathrm{a}}$ & $1.88 \pm 0.03^{a}$ & $1.05 \pm 0.01^{\mathrm{a}}$ \\
\hline SS95SM5 & $0.144 \pm 0.004^{c}$ & $0.303 \pm 0.003^{c}$ & $0.070 \pm 0.004^{c}$ \\
\hline SS90SM10 & $0.263 \pm 0.003^{c}$ & $0.336 \pm 0.002^{c}$ & $0.121 \pm 0.003^{c}$ \\
\hline SS85SM15 & $0.442 \pm 0.002^{b}$ & $0.385 \pm 0.001^{b}$ & $0.198 \pm 0.001^{b}$ \\
\hline
\end{tabular}

Note: SS100SM0 = sorghum stem sheath extract, SM100SS0 = Spondias mombin extract, SS95SM5 = 95\% sorghum stem sheath + 5\% Spondias mombin extract, SS90SM10 $=90 \%$ sorghum stem sheath $+10 \%$ Spondias mombin extract, SS $85 S M 15=85 \%$ sorghum stem sheath $+15 \%$ Spondias mombin extract, Values are means \pm standard deviation of triplicate determinations. The mean values along the same column with different superscripts are significantly different $(p<0.05)$. 
The saponin level of the sorghum stem sheath - Spondias mombin extract ranged between $(0.070-0.198) \mathrm{mg} / 100 \mathrm{ml}$ which increased insignificantly $(p>0.05)$ with increased inclusion of Spondias mombin extract. The saponin content of the stem sheath $(0.018) \mathrm{mg} / 100 \mathrm{ml}$ was relatively lower than Moringa Oleifera extract $(2.500 \mathrm{mg} / 100 \mathrm{ml})$ [32]. Saponins have been found to cause haemolytic activity by reacting with the sterols of erythrocytes membrane [61]. The levels of this tested antinutrient in the enriched samples were low and within the tolerable (safe) levels for man which may not constitute any health hazard or mal-absorption of other nutrients when taken in large quantity (10 mg/ day) [59].

\section{Conclusion}

Data indicated higher nutritional compositions with low concentrations of anti-nutrients within consumable safe limits. This shows that the enriched samples can be potential sources of nutrients.

\section{Recommendation}

The physicochemical and antioxidant properties of the enriched samples could be studied for further research work.

Also, the shelf life of the extract under different preservative techniques could be evaluated.

\section{References}

1. FAO. Sorghum and Millets in Human nutrition. FAO (Food and Nutrition Series) 27. 1995.

2. Adetuyi AO, Pambang V, Oyetayo VO, Adetuyi FO. The Nutritive Value and Antimicrobial Property of Sorghum bicolor L. Stem (Poporo Flour Used as Food Colour Additive and its Infusion Drink. Am J Food Technol. 2007; 2: 79-86.

3. Adepoju OT, Oyewole EO. Nutrient composition and acceptability of fortified jam from Spondias mombin (Hog plum, (lyeye)) fruit pulp. Nigeria J Nutri Sci. 2008; 29: 180-189.

4. Adepoju OT, Karim SA. Nutrient composition, anti-nutritional factors and jam preparation from Spondias mombin (hog plum (lyeye)) fruit pulp. Nigeria J Nutri Sci. 2004; 25: 20-25.

5. Oladejo TA. Proximate Composition and Micronutrient Potentials of Three Locally Available Wild Fruits In Nigeria. African J Agric Res. 2009; 4: 887-892.

6. Akubor PI, Egbekun MK. Adepoju OT, Onasanya LO, Ogunfuwa AO, et al. Nutrient composition and acceptability test of juice and ice cream from Spondias mombin (Hog plum) fruit pulp extract. J Trop Med Resolut. 2006; 2007; 22: 25-32.

7. Oyewole EO, Adepoju OT. Nutrient composition and acceptability of honey-substituted jam from spondias mombin (Hog plum) fruit pulp. Nigeria J Nutr Sci. 2005; 26: 38-44.

8. Maldonado-Astudillo YI, Alia-Tejacal I, Nunez-Collin CA, JimenezHernandez J, Pelayo-Zaldivar C, et al. Postharvest physiology and technology of Spondias purpurea L. and S. mombin L. Scienta Horticulturae. 2014; 174: 193-206.

9. Ayoka AO, Akomolafe RO, Akinsomisoye OS, Ukponmwan OE. Medicinal and Economic Value of Spondias mombin Extract. African J Biomedical Res. 2008; 11: 129-136.
10. Mattietto RA, Matta V. Cajá ( Spondias mombin L.). In Yahia, E. (Ed). Postharvest Biology and Technology of Tropical and Subtropical Fruits. 2011; 2: 330-353.

11. Akther S, Shahriar SMS, Morshed FAS, Islam MN. Study on chemical composition of fresh Mymensingh and Barishal Hog-plum (Spondius mangifera) and developed leather and jelly and sensory evaluation weight of residue. Int J Environ Sci Nat Resour. 2012; 5:29-36.

12. Olayemi O, Salihu B, Allagh S. Evaluation of the binding properties of Spondias purpurea Gum in metronidazole tablet formulations. Int $\mathrm{J}$ Pharma Pharmaceut Sci. 2013; 5(Suppl 2): 584-589.

13. Arif M, Fareed S. Pharmacognostic investigation and authentication of potentially utilized fruit Spondias mangifera (wild). Int J Pharma Clin Res. 2010; 2: 31-35.

14. Tiburski JH, Rosenthal A, Deliza R, De Oliveira Godoy RL, Pacheco S. Nutritional properties of yellow mombin (Spondias mombin L.) pulp. Food Res Int. 2011; 44: 2326-2331.

15. Olayiwola IO, Akinfewa V, Oguntona C, Sanni S, Onabanjo O, Afolabi WA. Phytonutrient, antioxidant and mineral composition of some wild fruits Extract in south west Nigeria. Nigerian Food J. 2013; 31: 33-40.

16. Ayoka AO, Akomolafe RO, Iwalewa EO, Akanmu MA, Ukponmwan OE. Sedative, antiepileptic and antipsychotic effects of Spondias mombin L. (Anacardiaceae) in mice and rats. J Ethnopharmacol. 2006; 103: 166-175.

PubMed: https://pubmed.ncbi.nlm.nih.gov/16188408/

17. Njoku PC, Akumefula MI. Phytochemical and nutrient evaluation of Spondias mombin leaves Extract. Pakistan J Nutrition. 2007; 6: 613-615.

18. Igwe CU, Onyeze GOC, Onwuliri VA, Osuagwu CG, Ojiako AO. Evaluation of the chemical composition of the leaf Extract of Spondias mombin Linn from Nigeria. Aus J Basic Sci. 2010; 4: 706 - 710.

19. Ayoka AO, Akomolafe RO, Iwalewa EO, Ukponmwan OE. Studies on the anxiolytic effects of Spondias mombin L. (Anacardicaea) extracts. African J Traditional, Complemen Altern Med. 2005; 2: 153 - 165.

20. Fred-Jaiyesimi AA, Wilkins MR, Abo KA. Hypoglycaemic and amylase inhibitory activities of leaves of Spondias mombin Linn Extract. African J Med Medical Sci. 2009; 38: 343-349.

PubMed: https://pubmed.ncbi.nlm.nih.gov/20499628

21. Akinmoladun AC, Obuotor EM, Farombi EO. Evaluation of antioxidant and free radical scavenging capacities of some Nigerian indigenous medicinal plants. J Med Food. 2010; 13: 444-451.

PubMed: https://www.ncbi.nlm.nih.gov/pubmed/20192848

22. Aromolaran O, Badejo OK. Efficacy of fresh leaf extracts of Spondias mombin against some clinical bacterial isolates from typhoid patients. Asian Pac J Trop Dis. 2014; 4: 442 - 446.

23. Bolade MK, Oluwalana IB, Ojo OL. Commercial Practice of Roselle (Hibiscus sabdariffa) Beverage Production: Optimization of Hot Water Extraction and Sweetness Level. World J Agric Sci. 2009; 5: 126-131.

24. Sowonola OA, Akintunde TY, Adedeji F. Influence of Malting on the Nutritional Characteristics of Kunnu-zaki. African J Biotechnol. 2005; 5: 1-12.

25. Francini A, Sebastiani L. Phenolic Compounds in Apple (Malus $x$ domestica Borkh.): Compounds Characterization and Stability during Postharvest and after Processing. A Review on Antioxidants. 2013; 2: 181-193.

PubMed: https://www.ncbi.nlm.nih.gov/pmc/articles/PMC4665438/

26. AOAC. Official Methods of Analysis, (26 th edn). Association of Analytical Chemist, Washington D.C, USA. 2010.

27. Fashakin JB, Ilori MO, Olarewaju IB. Cost and Quality Optimization 
of a Complementary Diet from Plant Protein and Corn Flour using a Computer Aided Linear Programming Model. Nigerian Food J. 1991; 9: 123-127.

28. Hassan AS, Hassan HS. Quantitative estimation of vitamin C in some local fruits. Science World J. 2008; 3: 113-115.

29. Edet A, Eseyin O, Aniebiet E. Antinutrients composition and minera analysis of Allium cepa (onion) bulbs Extract. African J Pharm Pharmacol. 2005; 9: 456-459.

30. Price ML, van Scoyoc S, Butler LG. A critical evaluation of vanillin reaction as an assay for tannin in sorghum grain. J Agric Food Chem. 1978; $26: 1214-1218$

31. Brunner JH. Direct spectrophotometric determination of saponin. Annual Chem. 1984; 34: 1314-1326.

32. Ogbe AO, Affiku JP. Proximate Study, Mineral and Anti-Nutrient Composition of Moringa oleiferaLeaves Extract Harvested from Lafia, Nigeria: Potential Benefits in Poultry Nutrition and Health. J Microbiol, Biotechnol Food Sci. 2012; 1: 296-308.

33. Bola OA, Aboaba OO. Microbiological and Physico-chemical Evaluation of some Non- alcoholic Beverages. Pakistan J Nutri. 2004; 3: 188-192.

34. Egbere OJ, Anuonye JC, Chollom PF, Okpara PV. Effects of Some Preservation Techniques on the Quality and Storage Stability of Zobo Drink (A Nigerian, non-alcoholic beverage from Hibiscus sabdariffa). J Food Technol. 2007; 5: 225-228.

35. Moyo BB, Masika PJ, Hugo AA, Muchenje VV. Nutritiona Characterization of Moringa (Moringa Oleifera Lam.) Leaves Extract. African J Biotechnol. 2011; 10: 12925-12933.

36. Okaka JC. Development and Quality Evaluation of cowpea-wheat biscuits. Nigerian Food J. 2005; 8: 56-62.

37. Onyeka EU. Food and nutrition. 2nd Edition, Charismatic Forum Publisher, Owerri, Nigeria. 2008; 151.

38. Jimoh FO, Oladiji AT. Preliminary studies on Piliostigma thonningii seeds Extract: Proximate analysis, mineral composition and phytochemical screening. African J Biotechnol. 2005; 4: 1439-1442.

39. Chinma CE, Igyor DI. Physicochemical and Sensory Properties of Cookies Produced from Cassava/Soyabean/Mango Composite Flours. J Food Technol. 2007; 5: 256-260.

40. Ihekoronye Al, Ngoddy PO. Inhibition of three Fungal Isolates from Sorrel Drink (Zobo) using Hurdle Techniques. World J Agric Sci. 1985 3: 339 - 343.

41. Adepoju OT. Proximate composition and micronutrient potentials of three locally available wild fruits in Nigeria. African J Agric Res. 2009; 4: 887-892.

42. Nkamafiya II, Osemeahon SA, Dahiru D, Umaru HA. Studies on the chemical composition and physicochemical properties of the seeds Extract of baobab (Adasonia digitata). African J Biotechnol. 2007; 6 : 756-759.

43. Bamigboye AY, Okafor AC, Adepuju OT. Proximate and mineral composition of whole and dehulled sesame Extract. African J Food Sci Technol. 2010; 1: 71-75.

44. Onimawo IA. Proximate composition and selected physiochemical properties of the seed, pulp and oil of sour sop (Annona muricata). Plant Foods for Human Nutr. 2002; 57: 165-171.

45. Lohlum SA, Maikidi GH, Solomon M. Proximate composition, amino acid profile and phytochemical screening of Lophira lanceolata seeds Extract. African J Food Agric Nutrition Develop. 2010; 10: 2012-2023.
46. Bello MO, Falade OS, Adewusi SRA, Olawore NO. Studies on the chemical compositions and antinutrients of some lesser known Nigerian fruits. African J Biotechnol. 2008; 7: 3972-3979. S184.

47. Oladele IO. Application of Quality Protein Maize in the Formulation of Broiler's Finisher Feed. J Sci Food Hospitality. 2007; 1: 47-50.

48. Adedayo OA, Ganiyu O. Oluwaseun J, Agbebi A, Boligon A, et al. Sorghum [Sorghum bicolor (L.) Moench] Leaf Sheath Dye Protects Against Cisplatin-Induced Hepatotoxicity and Oxidative Stress in Rats. J Med Food. 2014; 17: 1332-1338.

PubMed: https://www.ncbi.nlm.nih.gov/pmc/articles/PMC4259168/

49. Awika JM, Rooney LW, Waniska RD. Properties of 3-deoxyanthocyanins from `sorghum Extract. J Agric Food Chem. 2004; 52: 4388-4394. PubMed: https://pubmed.ncbi.nlm.nih.gov/15237941

50. Oluwalana IB, Ade-Omowaye BIO, Adedeji TO. Nutritional Composition of a Non- Alcoholic Beverage Spiced with Zingiber officinale Extract Produced from Sorghum bicolor Stem sheath. Int J Food Sci Nutr Enginee. 2013; 3: 21-27.

51. Fuglie LJ. The Miracle Tree: Moringa oleifera Natural Nutrition for the Tropics. Training Manual. Church World Service, Dakar, Senegal. $2001 ; 34-46$

52. Bamishaiye EI, Olayemi FF, Bamishaiye OM. Effect of Boiling Time on Minerals and Vitamin C Content of three Varieties of Hibiscus Sabdariffa Drink in Nigeria. World J Agric Sci. 2011; 7: 62-67.

53. Omoba ML. Obalance AB, Martins DF, Madzvanuse M, Many ES. Manual of Laboratory Procedures for Quality Evaluation of Sorghum and Millet, International Crop Research Institute of the Semi Arid and Tropics (ICRSAT), India. 2013; 64.

54. Drugs Facts and Comparisons. Edition Editor: Bernie R. Olin, Published by Facts and Comparisons Division, J.B. Lippincott Company 111 West Port Plaze, Suite 432, USA. 1991

55. Otten JJ, Hellwig JP, Meyers LD. Dietary reference intakes: The essential guide to nutrient requirement. Washignton: The National Academies Press. 2006.

56. United States Department of Agriculture. Composition of Foods: Raw, Processed and Prepared Agriculture Research Services, USDA Nutrient Database Laboratory. USDA National Nutrient Database for Standard Reference. 2009.

57. Gbadegesin AR, Gbadamosi SO, Odunlade TV. Physicochemical and Sensory Properties of Pineapple Flavoured Powders. J Cogent Food Agric. 2017; 129-133.

58. Rai B, Anand SC. Serum and Salivary Vitamin C in Periodontal Disease: Adv Med Dent Sci. 2008; 2: 26

59. Health and Safety Publications. Permissible Levels of Antinutrients: Series on the Safety of Novel Foods, Feeds and Environment. 2011; 129-133

60. Osuntogun B, Aboaba O. Microbiological and Physico-chemical Evaluation of some Non-alcoholic Beverages. Pakistan J Nutr. 2004; 3: 188-192.

61. Gbadamosi SO, Famuwagun AA. Chemical, Functional and Antinutritional Properties of Fermented Kariya (Hilder gardiabarteri) Seed Protein Isolates. International Conference of Faculty of Technology, Obafemi Awolowo University, Ile- Ife. 2015; 5: 101-110.

62. Tsai J, Huang JK, Wu TT, Lee YH. Comparison of Oxalate Content in Foods and Beverages in Taiwan. J Technol Agric. 2005; 16: 93-98.

63. UPMC. Low Oxalate Diet: Patient Education Materials. Affiliated with the University of Pittsburgh Schools of the Health Sciences, Supplemental Content provided by Health- wise Incorporated. 2007. 
64. Mubarak AE. Nutritional Composition and Antinutritional Factors of Mung Beans as Affected by Some Home Traditional Processes. J Food Chem. 2005; 89: 489-495.

65. Fasoyiro SB, Ajibade SR, Omole AJ, Adeniyan ON, Farinde EO Proximate, Minerals and Antinutritional Factors of Some Underutilized Grain Legumes in the South West Nigeria. J Nutrition Food Sci. 2006; 36: $18-23$.
66. Albihn PBE, Savage GP. The Effect of Cooking on the Location and Concentration of Oxalate in Three Cultivars of New Zealand Grown Oca "(Oxalis tuberosa Mol). J Sci Food Agric. 2001; 81: 1027-1033.

67. Adelakun OE, Oyelade OJ, Ade-Omowaye BIO, Adeyemi I A, Van De Venter M. Chemical composition and the antioxidative properties of Nigerian okra seed (Abelmoschus esculentus Moench) Extract. Food Chem Toxicol. 2009; 47: 1123-1126.

PubMed: https://pubmed.ncbi.nlm.nih.gov/19425185 